\title{
An unusual cause of STEMI and cardiac tamponade
}

\author{
Khashayar Esfahani
}

Jewish General Hospital, McGill University, Montreal, Canada

\section{Correspondence to} Dr Khashayar Esfahani, khashayar.esfahani@mail. mcgill.ca

Accepted 8 October 2014

\section{DESCRIPTION}

A 28-year-old patient with refractory mediastinal B-cell lymphoma presented with acute onset of chest pain and shortness of breath. On clinical examination, the Beck triad of hypotension, distant heart sounds and elevated JVP was demonstrated. Furthermore, the patient was tachycardic and had a pulsus paradoxus of $20 \mathrm{~mm} \mathrm{Hg}$.

A bedside ECG (figure 1B) demonstrated diffuse low voltages and acute ST elevation in the anterolateral leads, different from the patient's baseline (figure 1A). These findings, in conjunction with the clinical examination, were worrisome for acute cardiac tamponade and ST elevation myocardial infarction (STEMI).
An infused CT of the chest demonstrated new masslike pericardial involvement of the heart from the previously known mediastinal lymphoma, without any associated pericardial effusion (figure 2). Involvement of the left heart explained the patient's STelevation in the anterolateral leads, while involvement of the right heart explained the patient's clinical symptoms of tamponade. The patient passed away shortly after hospital presentation.

Acute STEMI is a very rare complication of malignancy. Myocardial infarction in the setting of invasive malignancy is thought to be due to a combination of ischaemic infarction, altered oxygen consumption and tumour embolisation of coronary arteries. $^{12}$

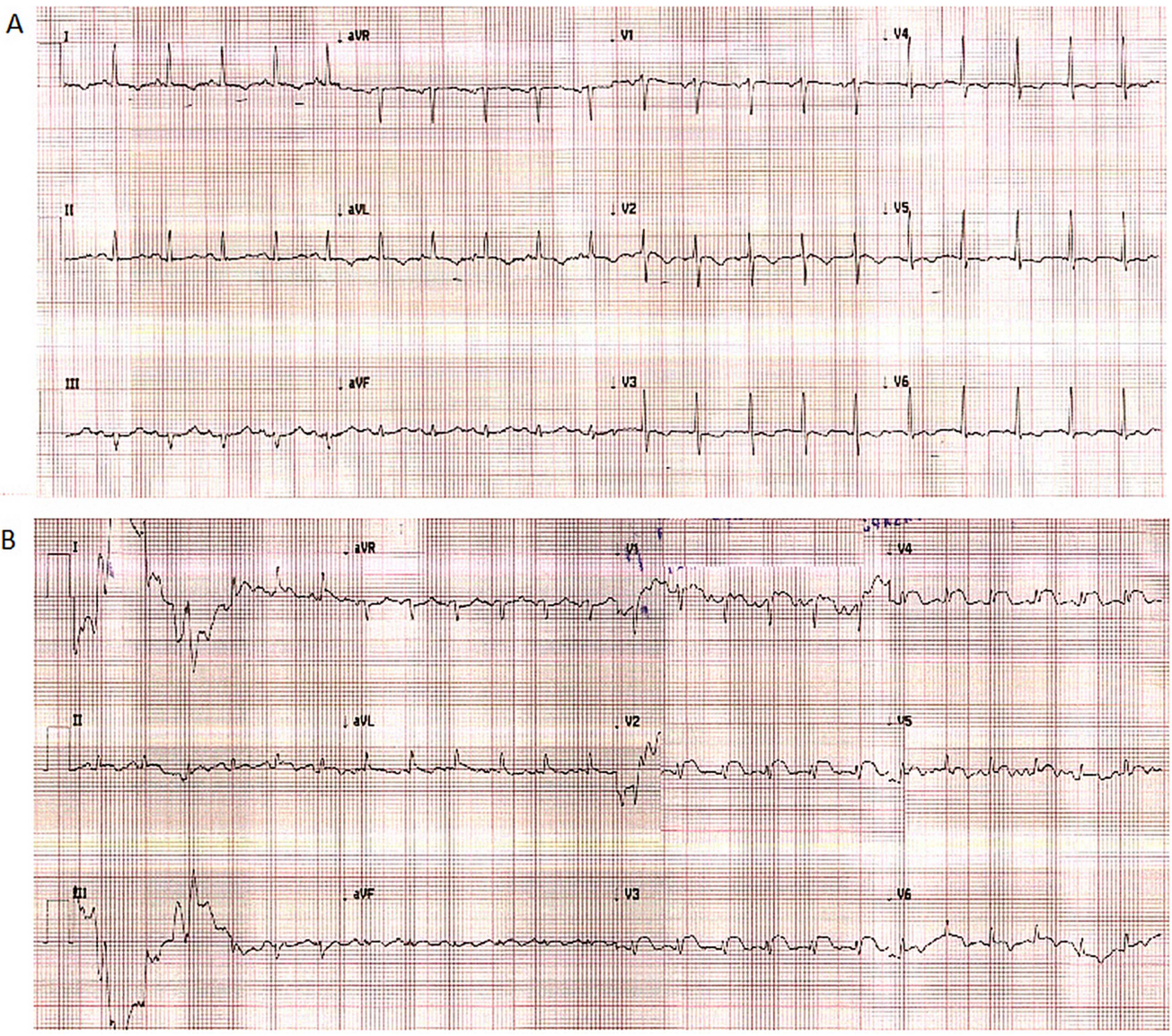

Figure 1 (A) Patient's baseline ECG (B) Diffuse low voltages as well as ST segment elevation in pericordial leads. 


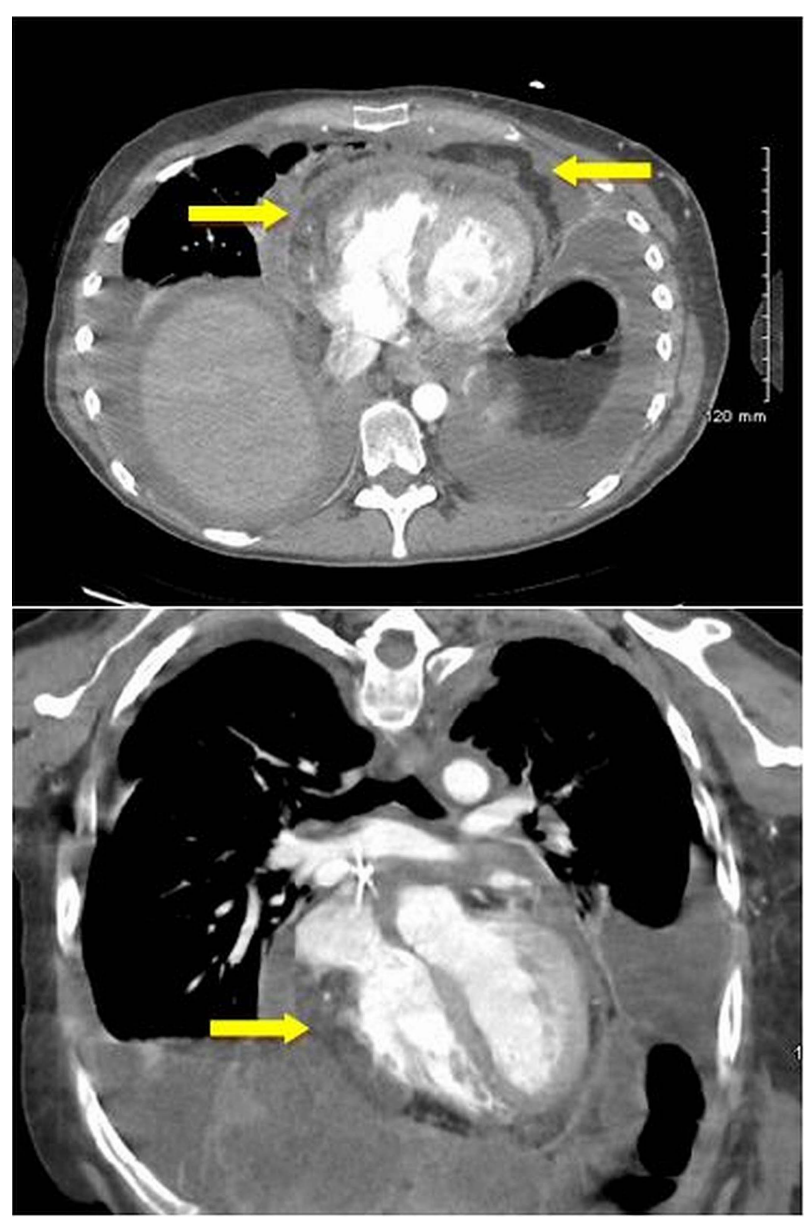

Figure 2 CT scan of the chest showing cardiac as well as pericoardial involvement by lymphoma.
Once there is significant pericardial involvement of a tumour, a tamponade physiology can also be created. The low voltages captured on the ECG are secondary to the underlying tumour between the heart and the ECG electrodes. The clinical symptoms of tamponade are generated once there is significant enough involvement of the pericardium to impair diastolic function.

\section{Learning points}

- Myocardial infarction is a rare complication of malignancy that requires a high clinical suspicion in the appropriate context for diagnosis.

- Adjunct medical imaging (CT or echocardiography) can be useful in establishing the correct diagnosis.

- Significant pericardial involvement of a tumour can create a tamponade physiology if there is impaired diastolic filling.

Competing interests None.

Patient consent None.

Provenance and peer review Not commissioned; externally peer reviewed.

\section{REFERENCES}

1 Leeies M, Weldon E. STEMI stymie: metastatic cancer and cardiac tamponade presenting as inferior STEMI. Ann Emerg Med 2011;57:221-4.

2 Ortega-Carnicer J, Benezet J, Porras L. Lung cancer presenting as cardiac tamponade associated with transmural myocardial ischaemia. Resuscitation 2001:51:317-20.

Copyright 2014 BMJ Publishing Group. All rights reserved. For permission to reuse any of this content visit http://group.bmj.com/group/rights-licensing/permissions.

BMJ Case Report Fellows may re-use this article for personal use and teaching without any further permission.

Become a Fellow of BMJ Case Reports today and you can:

- Submit as many cases as you like

- Enjoy fast sympathetic peer review and rapid publication of accepted articles

- Access all the published articles

- Re-use any of the published material for personal use and teaching without further permission

For information on Institutional Fellowships contact consortiasales@bmjgroup.com

Visit casereports.bmj.com for more articles like this and to become a Fellow 